Article

\title{
The Effect of Tree-Planting Patterns on the Microclimate within a Courtyard
}

\author{
Junying Li ${ }^{1,2,3, * \mathbb{C}}$, Jiying Liu ${ }^{2,4} \mathbb{D}$, Jelena Srebric ${ }^{2, *} \mathbb{C}$, Yuanman Hu ${ }^{5}$, Miao Liu ${ }^{5}$, Lei Su ${ }^{6}$ \\ and Shunchang Wang ${ }^{3}$ \\ 1 School of Life Science, Huizhou University, Huizhou 516007, China \\ 2 Department of Mechanical Engineering, University of Maryland, College Park, MD 20742, USA; \\ j.y.liu@hotmail.com \\ 3 College of Forestry, Shenyang Agriculture University, Shenyang 110866, China; scwong@sina.com \\ 4 School of Thermal Engineering, Shandong Jianzhu University, Jinan 250101, China \\ 5 Institute of Applied Ecology, Chinese Academy of Sciences, Shenyang 110016, China; huym@iae.ac.cn (Y.H.); \\ Lium@iae.ac.cn (M.L.) \\ 6 College of Art and Design, Zhongshan Institute, University of Electronic Science and Technology, \\ Zhongshan 528402, China; sulei@zsc.edu.cn \\ * Correspondence: jyli@hzu.edu.cn (J.L.); jsrebric@umd.edu (J.S.)
}

Received: 21 January 2019; Accepted: 11 March 2019; Published: 19 March 2019

check for updates

\begin{abstract}
Current landscape design within a courtyard usually does not take into account the influence of the tree-planting pattern, which has an important influence on the outdoor microclimate and occupants' thermal comfort. At present, the extent of the influence on the microclimate has not yet been made clear. Computational Fluid Dynamics (CFD) was employed to run this model under hot summer weather conditions. Field measurements validated the performance of the CFD model. This study conducted numerical simulations for five different tree-planting patterns, including (i) focused tree-planting (F), (ii) cornered tree-planting (C), (iii) multi-row tree-planting (R), (iv) surround tree-planting $(\mathrm{S})$ and $(\mathrm{v})$ no tree-planting $(\mathrm{N})$. Our study found that the tree-planting pattern affects both the distribution of air temperature and the degree of local heat transfer. Specifically, the C, S and $\mathrm{N}$ patterns allow for higher ventilation in the studied courtyard, while the $\mathrm{F}$ and $\mathrm{R}$ patterns cause lower wind velocities and associated courtyard ventilation. The average air temperature for the $C$ pattern is lower during summer afternoons than the other patterns. The wind flow pattern in the studied courtyard does not vary significantly with different tree-planting patterns. Nevertheless, the general relative humidity in the courtyard does not vary significantly with different tree-planting patterns, except for the $\mathrm{N}$ pattern. A future analysis is needed to investigate the mechanisms of the phenomenon.
\end{abstract}

Keywords: courtyard; tree-planting pattern; outdoor microclimate; PHOENICS

\section{Introduction}

At present, more than $50 \%$ of the world's population live in cities. The outdoor thermal environment in cities has become worse in recent years during summer, especially in residential areas, due to the Urban Heat Island (UHI) effect [1,2]. Artificial coverage and reduction of green areas are the main reasons for the deterioration in the outdoor environment [3-5]. On the local scale, green space, buildings and pavement are the factors that affect the environmental temperature [6,7]. Therefore, the construction of neighborhoods with more greenery and pervious surfaces with high albedo materials is a common method to counter the adverse effects of UHI [8,9]. Among these mitigation strategies, vegetation can provide additional transpiration cooling and shading that increases the 
overall shortwave reflectivity of a neighborhood as well as absorbing and storing less heat than building materials [10].

Courtyards, as spaces between urban and architectural scales, are commonly used, because they provide thermal comfort through several different heat transfer mechanisms. Specifically, courtyards provide shading and also support natural ventilation through the stack effect to ultimately create a cool microclimate within a neighborhood [11,12]. Courtyards tend to be the primary outdoor spaces for recreational activities as well. As a result, landscape architects focus on improving thermal comfort within courtyards during hot summers and cold winters $[13,14]$. Courtyards with a southward orientation and configurations of high Height/Width can achieve a better thermal comfort level both by shading during summer and regulating the wind speed in winter $[14,15]$. Specifically, trees provide both environmental and aesthetic benefits in neighborhoods with pervious surfaces and plants [16]. In landscape design, trees form the framework of an outdoor space and provide local climate control $[16,17]$. Compared with facades and roof greening, trees are more effective at reducing the temperature at the pedestrian level by a single vegetative unit [18]. Therefore, the planting of trees improves conditions in uncomfortable outdoor thermal environments, such as urban areas during summer. Trees also perform better than shrubs and grasses in mitigating human heat stress at the pedestrian level [6,19-21]. Among different characteristics, the Leaf Area Index (LAI), tree height and trunk height are the most influential factors on improving daytime comfort [22]. Most of the previous studies focused on tree planting on the street [23-26]. The planting of trees in park locations can influence the urban wind and thermal comfort [27]. Furthermore, tree-planting patterns around buildings can affect solar radiation and air flow in neighborhoods; thus, this has important effects on the thermal environment [28]. However, a few studies have focused on the cooling and ventilating mechanisms of tree-planting patterns at the neighborhood scale.

\section{The Subject of Research and Methods}

\subsection{Subject of Research}

This study compares and identifies the impacts of different tree-planting patterns on the neighborhood microclimate and summarizes suggestions for architectural landscape design. In this paper, a parametric study of the influence of the tree-planting pattern on the microclimate is presented. The study aims to answer the following questions: Does the tree-planting-pattern affect the microclimate within the courtyard? How does the tree-planting pattern influence the microclimate within a courtyard? Which is the best tree-planting pattern for a courtyard for summer usage? For different tree-planting patterns, which is the best location in the courtyard? If the landscape architectures want to select a certain position as a rest place, which tree-planting pattern should they choose to give the best microclimate? These findings can contribute to the development of guidelines for UHI mitigation measures. A description of the Computational Fluid Dynamics (CFD) model as well as the model description, model calibration and configuration of the study is presented in this section.

\subsection{Numerical Model}

This study uses Computational Fluid Dynamics (CFD) models to study the velocity, humidity and temperature distributions in a courtyard with different tree-planting patterns. Specifically, the model simulations use PHOENICS, a general-purpose computer program for predicting fluid flow and heat-transfer processes [29]. A turbulence model, a radiation flux model and a vegetation model are presented in this section.

\subsubsection{Turbulence Model}

The Re-Normalization Group (RNG) model was employed to account for the effects of smaller scales of motion. By using RNG methods, this model re-normalizes the Navier-Stokes equations. In the standard k-epsilon model, the eddy viscosity is determined from a single turbulence length 
scale, which occurs only at the specified scale, whereas, in reality, all scales of motion will contribute to turbulent diffusion. The RNG approach can be used to derive a turbulence model similar to the k-epsilon, resulting in a modified form of the epsilon equation, which attempts to account for the different scales of motion through changes to the production term. The control equations for outdoor airflow are the non-hydrostatic incompressible Navier-Stokes equations.

\subsubsection{Radiation Flux Model}

We used the IMMERSOL model [30] to simulate radiation. In the three-dimensional model, the distributions of solar radiation and long-wave radiation are affected by the ground, plants, buildings and other factors. PHOENICS uses a series of attenuation coefficients to describe the effects of these factors on the solar radiation and long-wave radiation. The direct solar radiation and diffused solar radiation were input into the PHOENICS model separately. The values of the attenuation coefficients ranged between 0 and 1 .

\subsubsection{Vegetation Model}

Vegetation affects the microclimate in the site in two aspects: the aerodynamics and the heat transfer. From an aerodynamic perspective, the main impact of vegetation on the environment is the reduction in air velocity and the additional turbulence levels produced by the canopy elements. A porous-media approach based on superficial velocities where momentum sinks, and turbulence sources are applied to a block of cells was chosen to represent the tree canopy. The influence of vegetation on the turbulent flow fields was modeled by including drag forces in the momentum equations and additional source terms in the transport equations for the turbulent kinetic energy $k$ and its dissipation rate $\varepsilon$. These drag forces are responsible for the deceleration of the wind flow inside the plant canopy and the additional turbulence source terms account for turbulence production and accelerated turbulence dissipation within the canopy [31]. The turbulent interactions between the airflow and the plant canopy are simulated by including the following additional source terms in the transport equations for $k$ and $\varepsilon$ :

$$
\mathrm{Sk}=\rho \mathrm{Cd} \alpha(z)(\beta p|U| 3-\beta d|U| k)
$$

and

$$
\mathrm{S} \varepsilon=\rho \mathrm{Cd} \alpha(z)\left(\frac{C 4 \varepsilon \beta p|U| 3 \varepsilon}{k}-C 5 \varepsilon \beta d|U| \varepsilon\right)
$$

where, $\beta p, \beta d, C 4 \varepsilon$ and $C 5 \varepsilon$ are empirical constants. The constant $\beta p$ represents the fraction of mean-flow kinetic energy converted to wake-generated $k$ by canopy drag and $\beta d$ is the fraction of $k$ dissipated by short-circuiting the Kolmogorov energy cascade [30]. Therefore, the source terms in these equations account for wake production, whereas the sink terms account for the spectral short cut associated with the production of turbulence in the wakes behind the individual canopy elements (branches, leaves, etc.). There is little consensus about their recommended values, which reflects the fact that different values are needed to match different sets of measured data [30]. The default values used in the PHOENICS implementation are those of Green [32] and the suggested values for $\beta p, \beta d, C 4 \varepsilon$ and $C 5 \varepsilon$ are 1.0, 4.0, 1.5 and 1.5 respectively. The LAI value was input according to the characteristics of the plant.

From a heat transfer prospect, the canopy can block the radiation from the sun, which can avoid heating of the ground under the canopy, therefore reducing the air temperature around the trees. The other process is the transpiration of the leaves, which can transfer the water in the leaves into water vapor, which absorbs heat from the surrounding air, reducing the air temperature around the trees. These processes are modeled by setting the parameters of radiation and heat source according to the LAI of the vegetation. The LAI and the drag force are important parameters that can be used to predict the influence of vegetation on the surrounding wind flow and air temperature environment. 


\subsubsection{Inlet Boundary Condition}

At the inlet of the computational domain, the logarithmic wind profile and the turbulence specification method, including turbulent kinetic energy $(k)$ and the turbulent dissipation rate $(\varepsilon)$, are given as equations [33-35]:

$$
\begin{gathered}
\frac{U(z)}{u^{*}}=\frac{1}{k} \ln \left(\frac{z+z_{0}}{z_{0}}\right) \\
k=\frac{u^{* 2}}{0.3} \\
\varepsilon=\frac{u^{* 3}}{k\left(z+z_{0}\right)}
\end{gathered}
$$

where $k$ is the von Karman constant $(k=0.4), u^{*}$ is the friction velocity and $z_{0}(=0.1 \mathrm{~m})$ is the roughness length. The uniform temperature is specified as the inlet boundary condition.

\subsection{Climate and Sites}

The studied courtyard is located in an idealized community with the weather conditions of College Park, MD, USA. The climate in this area is characterized by hot, humid summers and generally mild to cool winters. The average annual outdoor temperature in College Park is $13^{\circ} \mathrm{C}\left(55.4^{\circ} \mathrm{F}\right)$. The warmest month, on average, is July with an average temperature of $24.9^{\circ} \mathrm{C}\left(76.8^{\circ} \mathrm{F}\right)$. The coolest month, on average, is January with an average temperature of $1.2^{\circ} \mathrm{C}\left(34.1^{\circ} \mathrm{F}\right)$.

\subsection{Field Measurement and PHOENICS Calibration}

Validation of the PHOENICS simulation results was necessary to provide confidence in the accuracy of the simulation results.

To make sure the results of the study were validated, there was a need to validate the simulation results with the experimental measured results. Two variables are often used for the validation of outdoor microclimate modeling: (1) air temperature and (2) wind velocity. Previous studies indicated that the ground boundary conditions have an effect on the simulated air temperature. In this study, we employed an Infrared thermal camera to measure the surface temperature of the ground and the building surface.

The field experiment was performed in the residential area of the students' commons (Figure 1A), which are located in the south part of the campus of the University of Maryland (Figure 1B) in Maryland ( $\left.38^{\circ} 59^{\prime} 17^{\prime \prime} \mathrm{N}, 76^{\circ} 56^{\prime} 41^{\prime \prime} \mathrm{W}\right)$. The site consists of 1-6-storey buildings. The studied courtyard is surrounded by the 5-storey building located in the center of the area. There are two species of trees planted in the courtyard (Figure 2). The LAI of each tree was measured by LAI2000(LI-COR Inc, Lincoln, NE, USA). Detailed data of these trees are listed in Table 1. A meteorological station (No. 722244) is located $2.0 \mathrm{~km}$ to the southeast of the measured site at College Park Airport. This station provided the meteorological data for the simulation on the measurement day (Figure 1C).

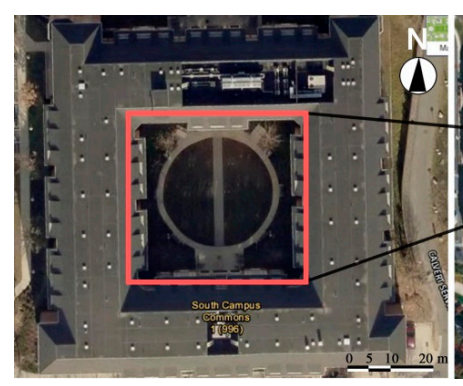

(A)

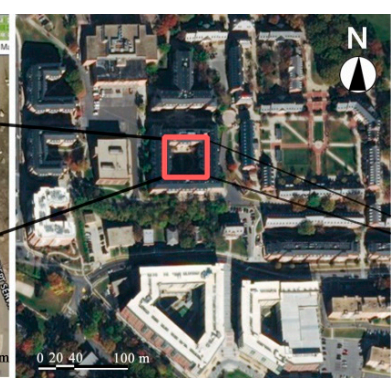

(B)

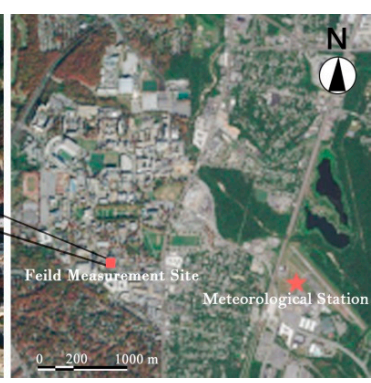

(C)

Figure 1. Location and surroundings of the study area: (A) field measurement domain (red outline); (B) simulated domain, (C) location of the meteorological station and field measurement site (red star and red rectangle). 


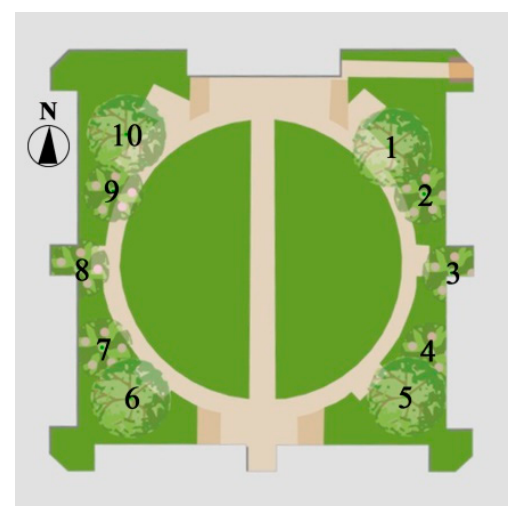

Figure 2. Distribution and the number of trees within the courtyard.

Table 1. Detailed data of trees planted in the courtyard (m).

\begin{tabular}{|c|c|c|c|c|c|c|c|}
\hline Number & Species & $\begin{array}{l}\text { Common } \\
\text { Name }\end{array}$ & $\begin{array}{c}\text { Tree } \\
\text { Height }\end{array}$ & $\begin{array}{l}\text { Crown } \\
\text { Height }\end{array}$ & $\begin{array}{l}\text { Crown } \\
\text { Radius }\end{array}$ & $\begin{array}{c}\text { Trunk } \\
\text { Height }\end{array}$ & $\begin{array}{c}\text { Leaf Area Index } \\
\text { (LAI) }\end{array}$ \\
\hline 1 & Acer saccharum & $\begin{array}{l}\text { Sugar } \\
\text { Maple }\end{array}$ & 8.3 & 4.4 & 2.2 & 3.9 & 3.3 \\
\hline 2 & Prunusserrulata & $\begin{array}{l}\text { Japanese } \\
\text { Cherry }\end{array}$ & 7.6 & 4.7 & 2.3 & 2.9 & 1.5 \\
\hline 3 & Prunusserrulata & $\begin{array}{l}\text { Japanese } \\
\text { Cherry }\end{array}$ & 7.1 & 3.7 & 1.9 & 3.4 & 1.4 \\
\hline 4 & Prunusserrulata & $\begin{array}{l}\text { Japanese } \\
\text { Cherry }\end{array}$ & 7.4 & 4.4 & 2.2 & 3.0 & 1.7 \\
\hline 5 & Acer saccharum & $\begin{array}{l}\text { Sugar } \\
\text { Maple }\end{array}$ & 10.1 & 5.0 & 2.5 & 5.1 & 3.7 \\
\hline 6 & Acer saccharum & $\begin{array}{l}\text { Sugar } \\
\text { Maple }\end{array}$ & 9.1 & 5.4 & 2.7 & 3.7 & 3.2 \\
\hline 7 & Prunusserrulata & $\begin{array}{l}\text { Japanese } \\
\text { Cherry }\end{array}$ & 7.5 & 4.1 & 2.0 & 3.5 & 2.0 \\
\hline 8 & Prunusserrulata & $\begin{array}{l}\text { Japanese } \\
\text { Cherry }\end{array}$ & 7.3 & 5.3 & 2.7 & 2.0 & 2.3 \\
\hline 9 & Prunusserrulata & $\begin{array}{l}\text { Japanese } \\
\text { Cherry }\end{array}$ & 7.9 & 5.9 & 3.0 & 2.0 & 2.2 \\
\hline 10 & Acer saccharum & $\begin{array}{l}\text { Sugar } \\
\text { Maple }\end{array}$ & 8.6 & 4.3 & 2.2 & 4.2 & 3.5 \\
\hline
\end{tabular}

Field measurements were performed from 9 a.m. to 3 p.m. on 20 September 2017. To understand the influence of trees on the microclimate within the courtyard, this study considered the effects of shaded/sunlit areas and pervious/impervious surfaces for temperature and wind velocity measurement. Thus, 7 various locations were selected for data collection (Figure 3). Kestrel 5400 Heat Stress Tracker (Nielsen-Kellerman Co, Boothwyn, PA, USA) equipped with a wind vane were selected to measure the air temperature and wind velocity at the same time. The sensors used for monitoring presented the following characteristics:

- The accuracy of the measured temperature was $\pm 0.5^{\circ} \mathrm{C}$ within the temperature range -29.0 to $70.0^{\circ} \mathrm{C}$.

- The accuracy of the wind velocity was $\pm 3 \%$ of reading within the airspeed range 0.6 to $40.0 \mathrm{~m} / \mathrm{s}$, least significant digit or $20 \mathrm{ft} / \mathrm{min}$.

- $\quad$ The response time of the sensors was $2 \mathrm{~s}$. 


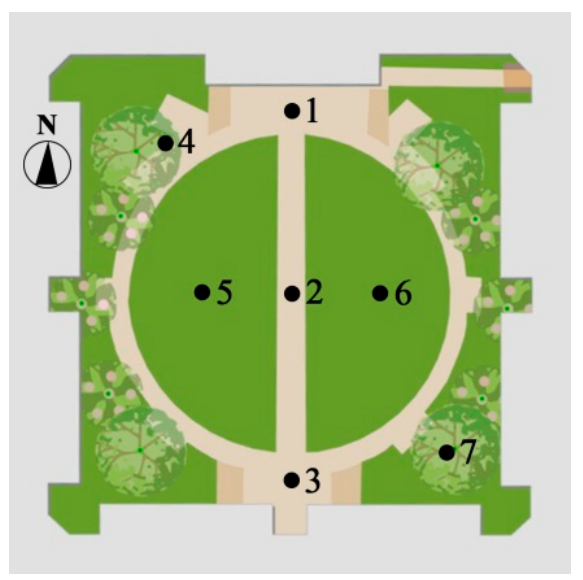

Figure 3. The distribution of tested points within the courtyard at 2:00 p.m. on 20 September 2017: $(1,2)$ sunlit paving, (3) building shaded paving, (4) tree shaded paving, $(5,6)$ sunlit grass, $(7)$ tree shaded grass.

All meters were mounted on the tripods at a height of $1.5 \mathrm{~m}$, representing the pedestrian height, which is the elevation that is most sensitive to human thermal comfort. Climate date such as air temperature and wind velocity were recoded every 2 min into the logger embedded in the meter and were averaged every $30 \mathrm{~min}$ for analysis. The study also used the FLIR E40 camera (FLIR-Systems Inc, Wilsonville, OR, USA), which has a thermal sensitivity of $0.07^{\circ} \mathrm{C}$ and a resolution of $160 \times 120$ pixels (19,200 total pixels), to capture IR images and measure temperature readings from the ground and building surface at 2:00 p.m. (Figure 4). The temperature readings were input into the model to initialize the simulation (Table 2). The solar absorption and emissivity of building roofs, concrete pavement and building walls were input into the model too [36].
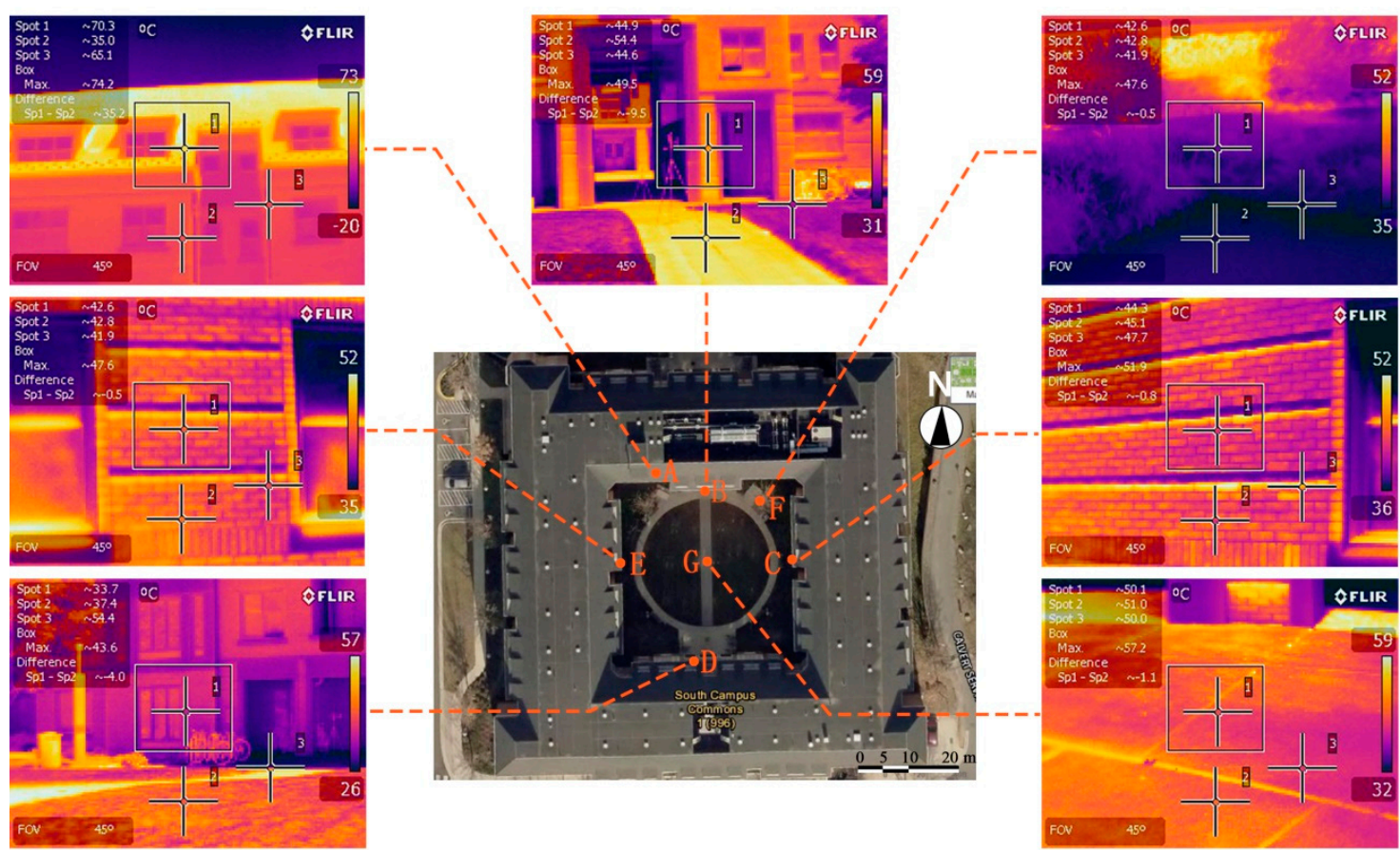

Figure 4. The infrared (IR) images for the ground and building surfaces. 
Table 2. Summary of the inputs into the validation assessment of the Computational Fluid Dynamics (CFD) model.

\begin{tabular}{|c|c|}
\hline Parameters & Summary of Inputs \\
\hline Simulation day & 20 September 2017 \\
\hline Simulation time & 2:00 p.m. \\
\hline Spatial resolution & $\begin{array}{c}1.0 \mathrm{~m}(3.3 \mathrm{ft}) \text { horizontally } \\
0.2 \mathrm{~m}(0.7 \mathrm{ft}) \text { vertically }\end{array}$ \\
\hline Longitude & $76^{\circ} 56^{\prime} 41^{\prime \prime} \mathrm{W}$ \\
\hline Latitude & $38^{\circ} 59^{\prime} 17^{\prime \prime} \mathrm{N}$ \\
\hline Direct solar radiation & $816 \mathrm{~W} / \mathrm{m}^{2}$ \\
\hline Diffused solar radiation & $122 \mathrm{~W} / \mathrm{m}^{2}$ \\
\hline Initial air temperature & $28.8^{\circ} \mathrm{C}$ \\
\hline Wind speed (at $10 \mathrm{~m}$ ) & $3.1 \mathrm{~m} / \mathrm{s}(9.3 \mathrm{ft} / \mathrm{s})$ \\
\hline Wind direction $(\mathrm{N}=0, \mathrm{E}=90)$ & $350^{\circ}$ \\
\hline Building surface temperature & $\mathrm{E}: 44.3^{\circ} \mathrm{C} ; \mathrm{W}: 41.9^{\circ} \mathrm{C} ; \mathrm{N}: 44.9^{\circ} \mathrm{C} ; \mathrm{S}: 33.7^{\circ} \mathrm{C}$ \\
\hline Ground surface temperature (concrete) & $51.0^{\circ} \mathrm{C}$ \\
\hline Roof surface temperature & $70.3^{\circ} \mathrm{C}$ \\
\hline Relative humidity & $45 \%$ \\
\hline Drag coefficient & 0.5 \\
\hline Solar absorption for brick walls & 0.75 \\
\hline Emissivity for brick walls & 0.90 \\
\hline Solar absorption for concrete pavement & 0.74 \\
\hline Emissivity for concrete pavement & 0.94 \\
\hline Solar absorption for roofs & 0.87 \\
\hline Emissivity for roofs & 0.88 \\
\hline
\end{tabular}

The PHOENICS model was built based on the actual configuration of the site. The building surrounding the interested courtyard was built in detail and the buildings isolated from the courtyard were modeled without detailed information of less than $1 \mathrm{~m}$ resolution. Trees, poles and cars outside the courtyard and poles, bicycles and benches inside the courtyard were neglected in the simulation. The weather data on the simulated time obtained from the College Park Airport were input into the model.

Based on the literature recommendations, verification and validation are important aspects of each CFD simulation. Verification requires demonstration that the model represents the mathematical model. The Grid Convergence Index (GCI) is a measure to verify the model's convergence rate. Therefore, this study used the following equation to assess the GCI of the simulation results:

$$
G C I=\frac{F_{S}|\in|}{\left(r^{p}-1\right)}
$$

where, $F s, \varepsilon, r$ and $p$ are the safe factor, the error between the current and refined mesh, the grid improvement factor and the order of convergence, respectively. In this study, we used the hexahedron grid; thus, the grid improvement factor for this simulation was 1.2. Fs was 1.25 and the calculated convergence rate was 1.25 . This study used a refined grid of $1.0 \times 1.0 \mathrm{~m}(3.3 \times 3.3 \mathrm{ft})$ horizontally and $0.2 \mathrm{~m}(0.7 \mathrm{ft})$ vertically within the courtyard to reach an average GCI of $1.5 \%$ for the air temperature and $5.6 \%$ for the wind velocity. Therefore, within the courtyard, the refined grid was set as $1.0 \times 1.0 \mathrm{~m}$ $(3.3 \times 3.3 \mathrm{ft})$ horizontally and $0.2 \mathrm{~m}(0.7 \mathrm{ft})$ vertically. 
The data from monitoring locations were extracted from the simulation results. Figure 5 shows the observed and simulated air temperature and wind velocity at 2:00 p.m. on the measured day. The simulation results of the air temperature were similar to the field data. The air temperature difference and wind velocity difference between the measured and simulated data were $0.3-0.9{ }^{\circ} \mathrm{C}$ and $0.1-0.4 \mathrm{~m} / \mathrm{s}$ respectively (Figure $5 \mathrm{a}, \mathrm{b}$. The average temperature deviation was $0.6{ }^{\circ} \mathrm{C}$ and the average wind velocity deviation was $0.1 \mathrm{~m} / \mathrm{s}$. The wind velocity showed more variation in the field test than in the simulated results due to the more complex wind environment in reality. The air temperature measured on site was a little higher than the simulated data. This may have been caused by the exposure of the weather meters to sunshine, which could have caused the surface of the meter to have a higher temperature, thus warming the air around the meter's sensor. The wind velocity within the courtyard was low on the measured day, which would have aggravated this heating process. The results indicated that the simulation using PHOENICS approximated the actual measurements from the fitted regression lines shown in the scatterplots (Figure $5 c, y=0.4038 x+17.032$ and $(d)$, $y=0.8609 x+0.0093)$. The PHOENICS model is capable of simulating the microclimate in a courtyard with greenery in the hot summer season.
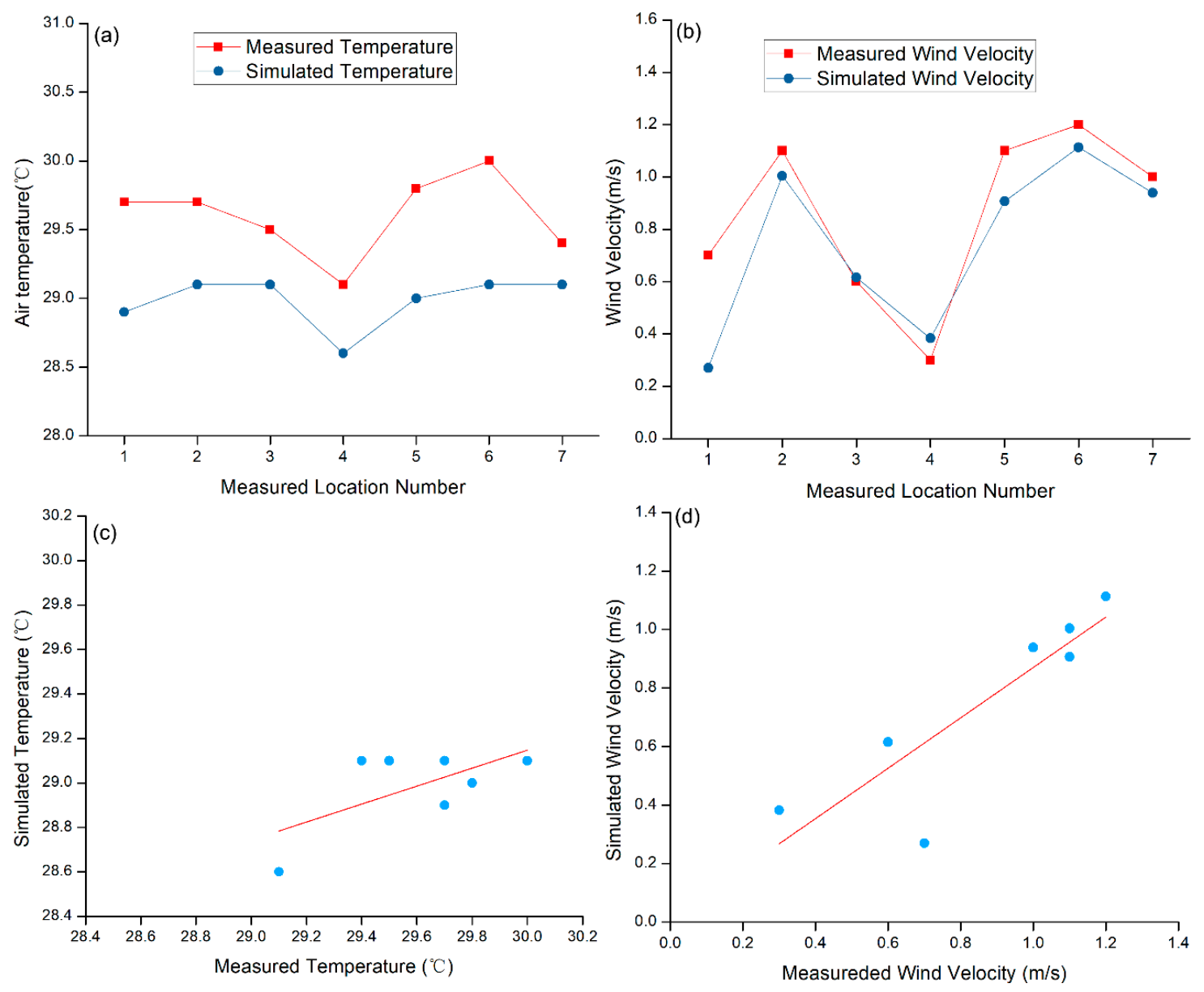

Figure 5. Comparison of measured and simulated results: (a) air temperature, (b) wind velocity. The mentioned data are compared in scatterplots: (c) air temperature, (d) wind velocity.

\subsection{Numerical Experimentation Setup and Configuration}

The studied courtyard is located in an ideal community presented in Figure 6. In the community, there are 9 cube buildings, each building with a façade of red bricks (Figure 6). The studied courtyard has dimensions of $38 \times 38 \mathrm{~m}$ and is surrounded by residential buildings. The size of each building is $86 \times 86 \times 13.5 \mathrm{~m}(282 \times 282 \times 44 \mathrm{ft})(\mathrm{L} \times \mathrm{W} \times \mathrm{H})$ and each building has 5 floors with a floor-to-floor 
height of $2.7 \mathrm{~m}(8.9 \mathrm{ft})$. The width of the streets between the buildings is $86 \mathrm{~m}(282 \mathrm{ft})$. A distance of $15 \mathrm{H}(202.5 \mathrm{~m}, 664.2 \mathrm{ft})$ between the inflow boundary and the first building and a distance of $15 \mathrm{H}$ $(202.5 \mathrm{~m}, 664.2 \mathrm{ft})$ between the outlet boundary and the last building of the domain were set according to previous studies $[30,37,38]$.

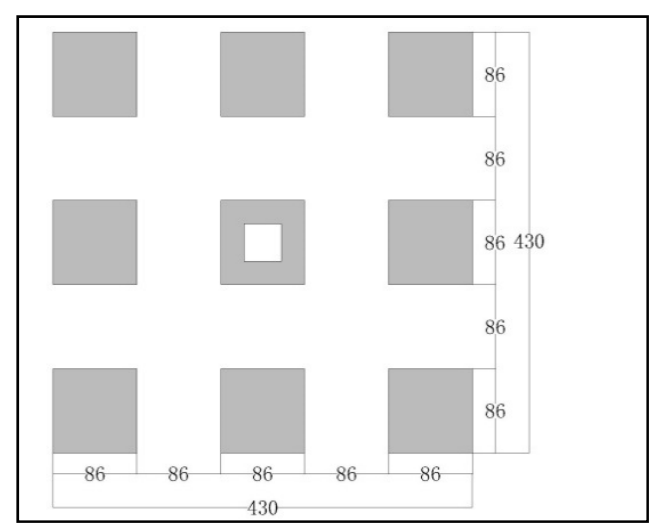

(A)

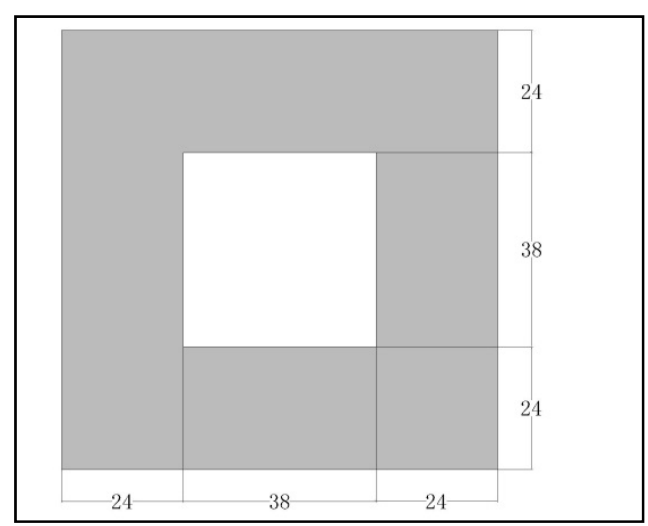

(B)

Figure 6. The general block of the residential community and courtyard used for the simulation $(\mathrm{m})$ : (A) residential community, (B) courtyard used for simulation.

In addition, a distance of $5 \mathrm{H}(67.5 \mathrm{~m}, 221.4 \mathrm{ft})$ between the top boundary of the domain and the top of the highest building surface was set according to the Working Group of the Architectural Institute of Japan (AIJ) [39,40]. For all simulation cases, the computational domain covered a horizontal area of $970 \times 970 \mathrm{~m}(3182 \times 3182 \mathrm{ft})$ and a vertical height of $90 \mathrm{~m}(295 \mathrm{ft})$. In order to generate a fully developed flow, the outflow at the outlet boundary was imposed with an aero-gradient. Buildings surrounding the analyzed courtyard were modeled explicitly in detail. Other buildings in the neighborhood were modeled as blocks. Within the courtyard, the refined grid was set as shown in Figure 7; Figure 8.

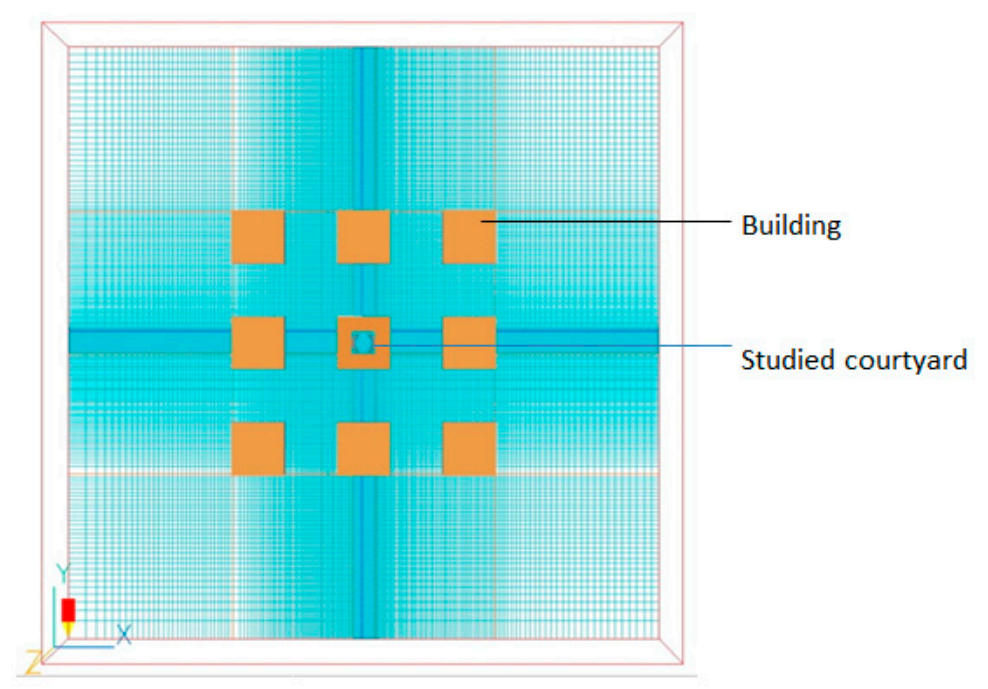

Figure 7. Grid distribution in the simulation domain. 


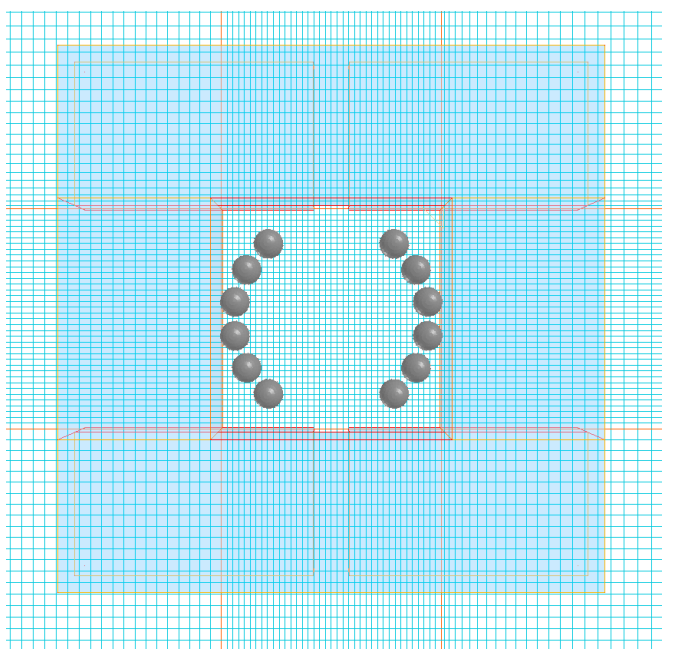

Figure 8. Local grid distribution within the courtyard.

For the base cases, five courtyard settings with and without tree-planting were modeled. The horizontal view for each case is presented in Figure 9, including the focused tree-planting pattern $(\mathrm{F})$, the cornered tree-planting pattern $(\mathrm{C})$, the multi-row tree-planting pattern $(\mathrm{R})$, the surrounding tree-planting pattern $(\mathrm{S})$ and the no tree-planting pattern $(\mathrm{N})$. The embedded trees were of the same LAI (LAI = 4) with the same crown diameter of $5 \mathrm{~m}(16 \mathrm{ft})$ and the same trunk height of $2.0 \mathrm{~m}(6.7 \mathrm{ft})$. For each scenario, there were twelve trees planted in the courtyard with no overlapping of tree crowns, which resulted in the same tree-covered area (TCA). The trees were placed at $5 \mathrm{~m}(16 \mathrm{ft})$ intervals with overlapping joint crowns for $\mathrm{F}$ and $\mathrm{C}$ tree-planting patterns. Trees were placed in the two north corners of the courtyard for the $\mathrm{C}$ pattern, because that is the best location for trees to grow due to the exposure to additional solar radiation in comparison with the exposure in other corners. For the $\mathrm{S}$ tree-planting pattern, trees were placed evenly along a circle with openings for an entrance at both north and south sides of the circle. Trees were placed evenly in 3 rows and 4 columns for the $\mathrm{R}$ tree-planting pattern. A comparative case with the $\mathrm{N}$ tree-planting pattern was set in the courtyard.

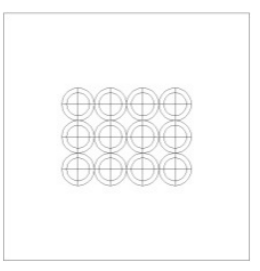

(F)

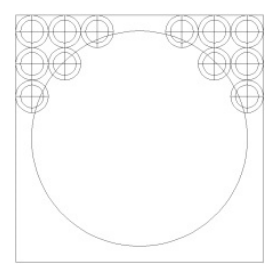

(C)

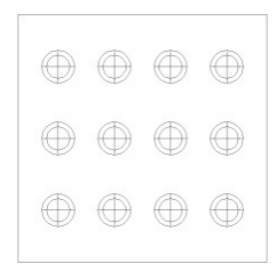

$(\mathrm{R})$

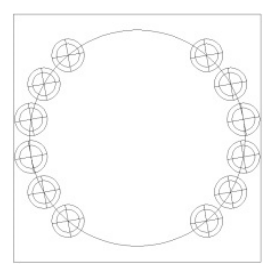

(S)

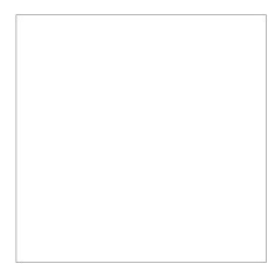

$(\mathrm{N})$

Figure 9. Tree-planting patterns for the five scenarios.

\subsection{Model Initialization}

The simulated models were initialized with meteorological input on 5 August 2015, which was a typical hot summer day in College Park, MD, USA. In summer, the average temperature is $22.6{ }^{\circ} \mathrm{C}$ $\left(72.7^{\circ} \mathrm{F}\right)$ in College Park with high levels of humidity. Afterwards, the weather conditions were used to check the potential of the different tree-planting patterns to provide a comfortable microclimate in summer. The LAI is set as 4 , assuming that the trees were healthy and fully grown common broad leaf trees [41]. Cpe4 and Cpe5 were both set to 1.5 according to PHOENICS instructions [32]. In order to simplify the model, the ground within the courtyard was assumed to be an adiabatic plate that had no heat exchange with the air around it. A summary of the inputs of the simulation of the CFD model is given in Table 3. 
Table 3. The summary of the inputs in the simulation of the CFD model.

\begin{tabular}{|c|c|}
\hline Parameters & Summary of Inputs \\
\hline Simulation day & 5 August 2015 \\
\hline Simulation time & 2:00 p.m. \\
\hline Spatial resolution & $\begin{array}{c}1.0 \mathrm{~m}(3.3 \mathrm{ft}) \text { horizontally } \\
0.2 \mathrm{~m}(0.7 \mathrm{ft}) \text { vertically }\end{array}$ \\
\hline Longitude & $76^{\circ} 56^{\prime} 41^{\prime \prime} \mathrm{W}$ \\
\hline Latitude & $38^{\circ} 59^{\prime} 17^{\prime \prime} \mathrm{N}$ \\
\hline Direct solar radiation & $829 \mathrm{~W} / \mathrm{m}^{2}$ \\
\hline Diffused solar radiation & $160 \mathrm{~W} / \mathrm{m}^{2}$ \\
\hline Initial air temperature & $31.0^{\circ} \mathrm{C}$ \\
\hline Wind speed (at $10 \mathrm{~m}$ ) & $5.7 \mathrm{~m} / \mathrm{s}(18.8 \mathrm{ft} / \mathrm{s})$ \\
\hline Wind direction $(\mathrm{N}=0, \mathrm{E}=90)$ & $190^{\circ}$ \\
\hline Building surface temperature & E: $45.3^{\circ} \mathrm{C} ; \mathrm{W}: 41.6^{\circ} \mathrm{C} ; \mathrm{N}: 46.9^{\circ} \mathrm{C} ; \mathrm{S}: 36.9^{\circ} \mathrm{C}$ \\
\hline Ground surface temperature (concrete) & $49.5^{\circ} \mathrm{C}$ \\
\hline Roof surface temperature & $56.0^{\circ} \mathrm{C}$ \\
\hline Relative humidity & $31 \%$ \\
\hline Drag coefficient & 0.5 \\
\hline Solar absorption for brick walls & 0.75 \\
\hline Emissivity for brick walls & 0.90 \\
\hline Solar absorption for concrete pavement & 0.74 \\
\hline Emissivity for concrete pavement & 0.94 \\
\hline Solar absorption for roofs & 0.87 \\
\hline Emissivity for roofs & 0.88 \\
\hline
\end{tabular}

All tree-planting pattern scenarios were set to run with these parameters until the residual error reduced to under $0.01 \%$. The average air temperature, humidity and wind velocity were recorded and put into Microsoft Excel and these data are presented in the following paragraph. The influence of the tree-planting pattern on the air temperature, relative humidity, wind velocity and wind direction were analyzed in detail. The distribution pattern of the air temperature, wind velocity and relative humidity were also studied in this paper and a comparison between the five patterns was carried out using sampled transects from the south to north within the courtyard.

\section{Result and Discussion}

This study analyzed the impact of tree-planting patterns on the courtyard air temperature, wind velocity, wind direction and relative humidity to further infer their impacts on the local microclimate in the studied courtyard.

\subsection{Impact of the Tree-Planting Pattern on the Average Air Temperature, Humidity and Wind Velocity}

The average air temperature is the most representative parameter of the overall thermal comfort of the courtyard. Table 4 shows that the $\mathrm{N}$ pattern led to the highest average air temperature among the five patterns. This means that planting trees in the courtyard can make it cooler, no matter which tree-planting pattern is chosen. The tree-planting pattern generally influenced the effect of air temperature reduction. The decreasing order for the average air temperature for different tree-planting patterns on a hot summer afternoon was C, F, R and then S. So, the commonly used tree-planting pattern in the USA is not appropriate for the area on hot, humid summer days, as it reduced the 
average air temperature the least. The difference in the average air temperature was almost $1{ }^{\circ} \mathrm{C}$ $\left(0.87^{\circ} \mathrm{C}\right.$, between the $\mathrm{N}$ and $\mathrm{C}$ patterns).

Table 4. Average air temperature, relative humidity and wind velocity within the courtyard for the five tree-planting patterns.

\begin{tabular}{ccccc}
\hline Number & Pattern & $\begin{array}{c}\text { Air Temperature } \\
\left({ }^{\circ} \mathbf{C}\right)\end{array}$ & $\begin{array}{c}\text { Relative Humidity } \\
(\mathbf{\%})\end{array}$ & $\begin{array}{c}\text { Wind Velocity } \\
(\mathbf{m} / \mathbf{s})\end{array}$ \\
\hline 1 & $\mathrm{~F}$ & 31.92 & 29.52 & 1.30 \\
2 & $\mathrm{C}$ & 31.79 & 29.72 & 1.35 \\
3 & $\mathrm{R}$ & 31.95 & 29.50 & 1.30 \\
4 & $\mathrm{~S}$ & 32.14 & 29.16 & 1.34 \\
5 & $\mathrm{~N}$ & 32.66 & 28.23 & 1.54 \\
\hline
\end{tabular}

The relative humidity of air for the $\mathrm{N}$ pattern was the lowest among the five patterns, which means that planting trees in the courtyard can increase the air humidity. The $\mathrm{C}$ pattern increased the average humidity the most, while the $S$ pattern increases it the least. The average humidity increase for the $F$ and $R$ patterns was nearly the same and fell between the increases of the $S$ and $C$ patterns.

For the average wind velocity, the four patterns with trees planting in the courtyard showed slightly lower values than the pattern with no trees.

\subsection{Impact of the Tree-Planting Pattern on the Air Temperature}

Air temperature is one of the most important factors that influences human thermal comfort on hot summer days. Figure 10 shows the air temperatures for the five tree-planting pattern scenarios within the courtyard at a height of $1.5 \mathrm{~m}(5 \mathrm{ft})$. For the air temperature at the pedestrian level with an approximate elevation of $1.5 \mathrm{~m}(5 \mathrm{ft})$ from the ground, cooler areas appeared in the southwest part of the courtyard in most of cases, except for in the $\mathrm{C}$ and $\mathrm{N}$ patterns. Also, the locations of the hottest areas were similar among different patterns. For all patterns, the east part of the courtyard along the walls was the hottest part of the courtyard. Hot areas were also observed in the north part along the north wall. For the F pattern, the southwest part was cooler than the northeast part. The coolest area was located in the south-central part near the entrance of the courtyard and the hottest area was located in the south along the east wall. This is due to the fact that trees planted densely in the center of the courtyard blocked the airflow, thus preventing the cool air from mixing with the hot air in the north part of the courtyard. As a result, the building walls in the north part of the courtyard were warmer than the walls in the other courtyard areas. Two important factors affecting the local air temperature were the incoming solar radiation and the wind shelter within the courtyard. The R pattern showed more cooler areas in most parts of the courtyard, because the trees planted in rows formed corridors that increased the wind velocity in the center of the courtyard, thus preventing the cool air from the west side from mixing with the warm air from the east side of the courtyard. The $\mathrm{N}$ pattern resulted in higher temperatures in both the south and north parts of the courtyard when compared with the temperatures in other patterns. Among the five studied patterns, the $S$ pattern created the highest local temperatures near the building wall at the north part of the courtyard and had the hottest area along three of the four walls in the courtyard. 


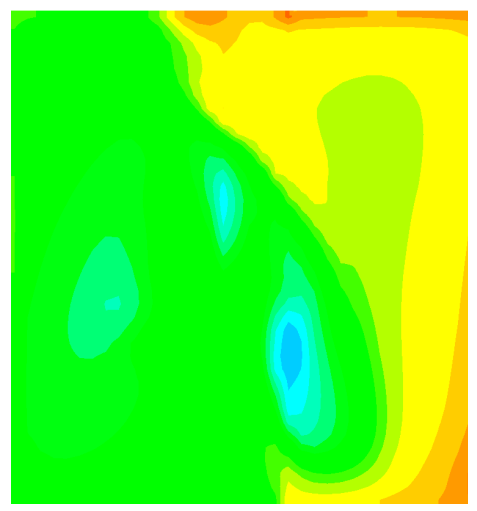

(F)

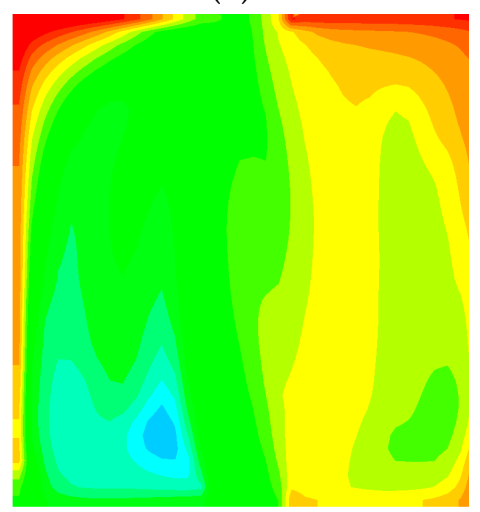

(S)

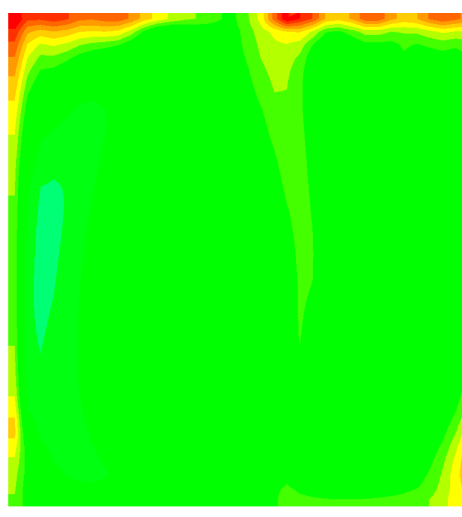

(C)

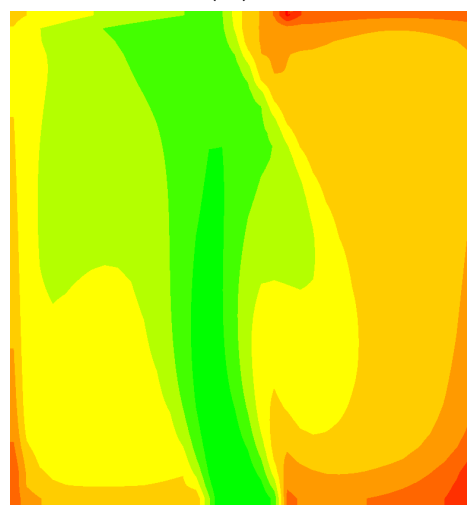

(N)

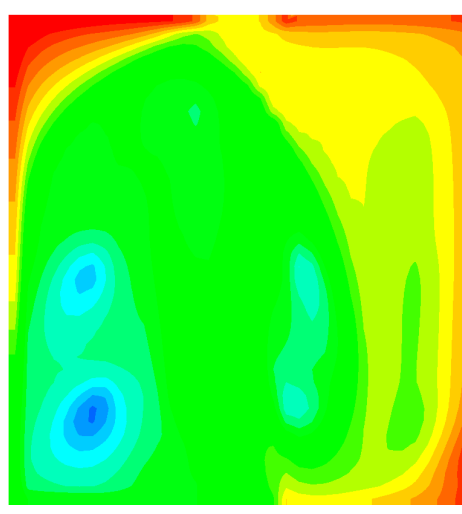

(R)

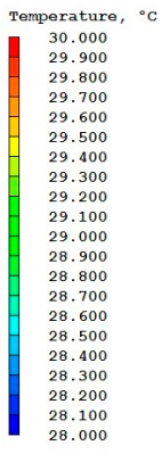

Figure 10. Air temperature for the five tree-planting pattern scenarios within the courtyard $(\mathrm{h}=1.5 \mathrm{~m})$.

The simulation results show that the tree-planting pattern not only affects the distribution of air temperature but also has an influence on the degree of local heat transfer. In order to get a cooler area in the south part of the courtyard to accommodate activities on summer afternoons, planting trees in evenly-spaced rows in the center of the courtyard is preferable. It is not recommended to plant trees surrounding the courtyard if the space along the north wall of the courtyard is used for recreation. When activities take place in the west part of the courtyard, planting trees in the center with a focused pattern in the courtyard is recommended.

Figure 11 shows three transects of air temperature from the west to the east of the courtyard at a height of $1.5 \mathrm{~m}$ above the ground. The three transects were sampled starting from west at the point of $1 \mathrm{~m}$ from the west building wall and ended in the east at the point of $1 \mathrm{~m}$ from the east building wall. The three transects were $1 \mathrm{~m}$ from the south building wall at the center of the courtyard and $1 \mathrm{~m}$ from the north building wall, respectively. From the south transect (Figure 11A), we can see that at the entrance of the courtyard where the wind comes into the courtyard, the air temperatures for the five tree-planting patterns were almost at the same level. However, in the west part and in the east part of the courtyard along the south building wall, the air temperature for the $\mathrm{N}$ pattern was much higher than for the other four patterns. The $S$ pattern had the lowest temperature along the south building wall in the west part of the courtyard and the difference between the $S$ and $N$ patterns reached nearly $2{ }^{\circ} \mathrm{C}$. The $\mathrm{C}$ pattern had the lowest temperature along the south wall in the east part of the courtyard and the difference between the $\mathrm{C}$ and $\mathrm{N}$ patterns was more than $1{ }^{\circ} \mathrm{C}$. If the south part along the wall is to be selected for use on summer afternoons, then the $S$ or $C$ pattern is recommended, according to which side is chosen. Figure $11 \mathrm{~B}$ shows that the $\mathrm{R}$ pattern reached an air temperature of nearly as low as $30{ }^{\circ} \mathrm{C}$ in the central part of the courtyard at both the west side and the east side. In the north part of the courtyard, the five patterns performed differently in the west part. The air temperature of the five patterns, from lowest to highest, was $\mathrm{F}<\mathrm{N}<\mathrm{C}<\mathrm{S}<\mathrm{R}$ (Figure 11C). In the east part, the temperature 
did not vary so much, except for with the $C$ pattern. The air temperature difference was no more than $1{ }^{\circ} \mathrm{C}$, which is not as much as that in the west part. For different activities taking place in the courtyard at 2:00 p.m. on a hot summer afternoon, which represents the most disadvantaged outdoor conditions in the courtyard in the summer period, different locations within the courtyard should be chosen; thus, different tree-planting patterns should be chosen.

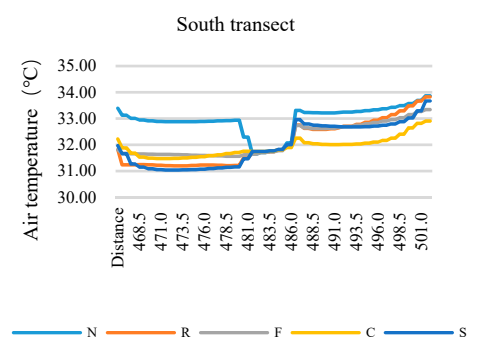

(A)

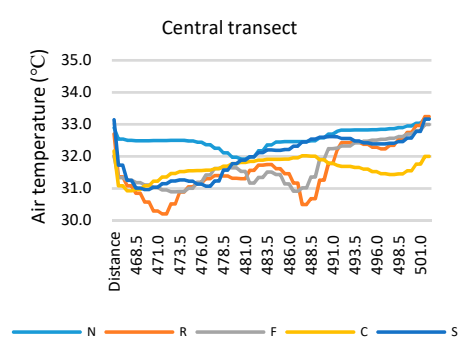

(B)

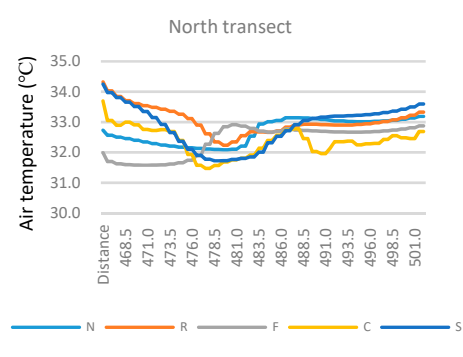

(C)

Figure 11. Transects for the air temperature from the west to the east: (A) south transect, (B) central transect, $(\mathbf{C})$ north transect.

\subsection{Impact of Tree-Planting Pattern on Wind Velocity}

An increase in wind velocity accelerates the evaporation of planted trees, locally decreasing the environmental temperature. Figure 12 shows the wind velocities for the five tree-planting pattern scenarios within the courtyard at a height of $1.5 \mathrm{~m}(5 \mathrm{ft})$. It was found that the wind velocity significantly

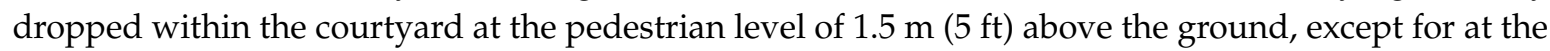
entrance where the wind enters the courtyard. For all patterns, the highest wind velocity was observed in the south-central part. The wind velocity significantly increased at the entrance of the courtyard, where the building walls are positioned parallel to the prevailing wind direction. In addition to in the central part, the wind velocity in the west part was lower than the velocity in the east part, especially for the $\mathrm{F}$ and $\mathrm{R}$ patterns. The results also indicate that the $\mathrm{F}$ and $\mathrm{R}$ patterns can have a significant effect on reducing the wind velocity in the west part of the courtyard. The wind velocity near the building walls in the west and east courtyard areas was higher than the velocity in the middle area for the $C$, $\mathrm{S}$ and $\mathrm{N}$ patterns. The wind forms vortexes when blocked by tree crowns in the central part of the courtyard. In the north part, the wind velocity was similar for the F, C and R patterns because the wind was blocked in these scenarios, while in the $S$ and $N$ patterns, the wind velocity was similar because there were no obstacles in the way. In the middle of the north part of the courtyard for the $F$ and $\mathrm{R}$ patterns, the wind velocity was lower than that of the other patterns where the trees planted in the central part of the courtyard blocked the wind it flowed through and around the tree crowns.

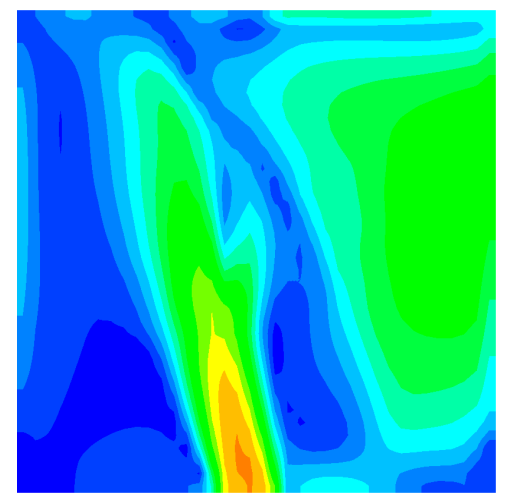

(F)

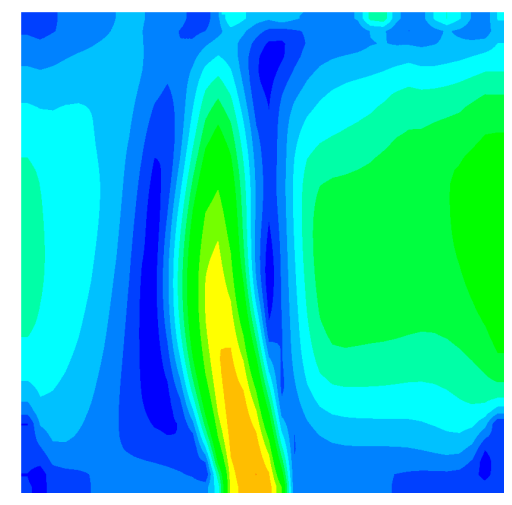

(C)

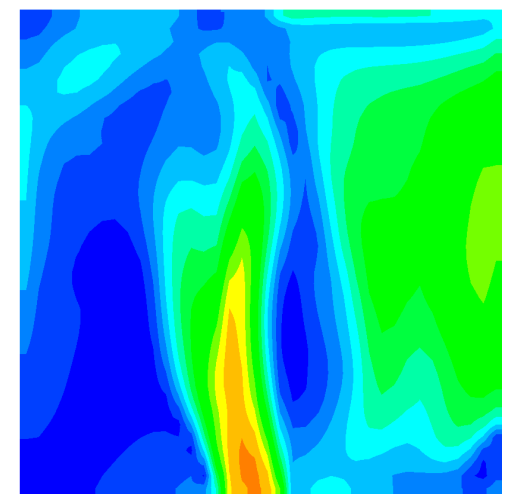

(R)

Figure 12. Cont. 


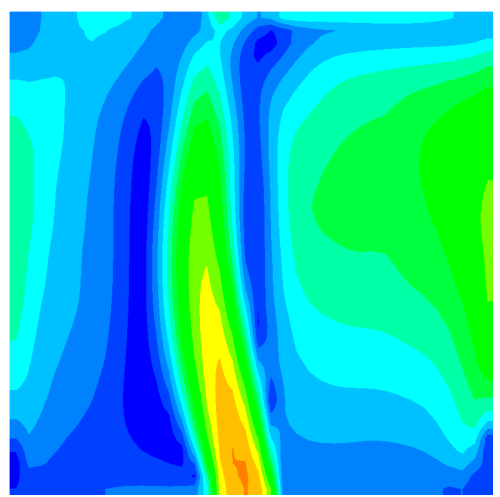

(S)

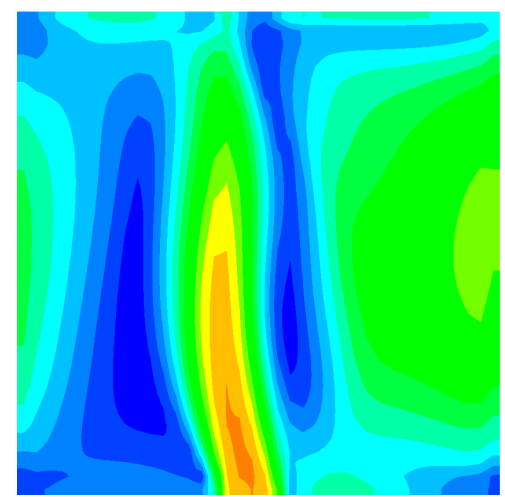

$(\mathrm{N})$

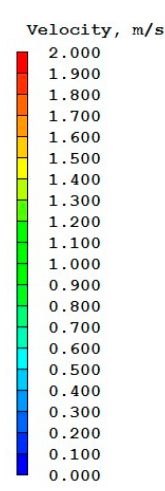

Figure 12. Wind velocity for the five tree-planting pattern scenarios within the courtyard $(\mathrm{h}=1.5 \mathrm{~m})$.

Figure 13 shows the three transects of wind velocity from the west to the east of the courtyard at a height of $1.5 \mathrm{~m}$ above the ground. The three transects were sampled in the same way as that of the air temperature. There was almost no difference in wind velocity among the five tree-planting pattern scenarios at the entrance of the courtyard where the wind enters the area (Figure 13A). The wind velocity in the southwest part of the courtyard was between 0 and $1 \mathrm{~m} / \mathrm{s}$, which is very slow, while in the southeast part of the courtyard, there were greater differences among the five tree-planting patterns. The $\mathrm{N}$ pattern reached more than $1.5 \mathrm{~m} / \mathrm{s}$, while the $\mathrm{C}$ pattern reached less than $1 \mathrm{~m} / \mathrm{s}$. In the central part the courtyard, the $\mathrm{F}$ and $\mathrm{R}$ patterns showed lower wind velocities along the west building wall and achieved lower wind velocity peaks than the other four patterns in the central part (Figure 13B). In the north part along the west building wall, the wind velocity for the $\mathrm{N}$ pattern was higher than that of the other four patterns (Figure 13C). The F pattern had the lowest wind velocity in the west and the $C$ pattern had the lowest in the east part of the courtyard.

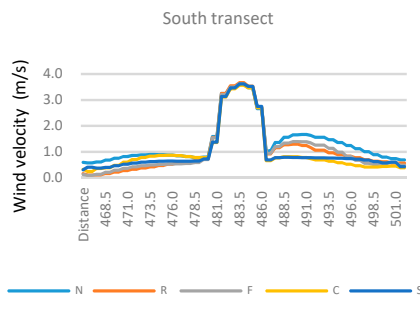

(A)

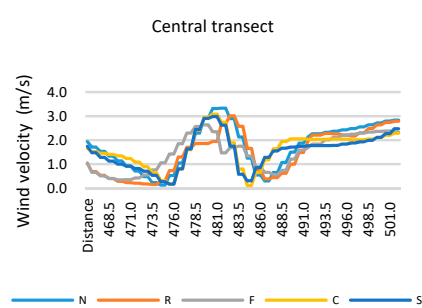

(B)

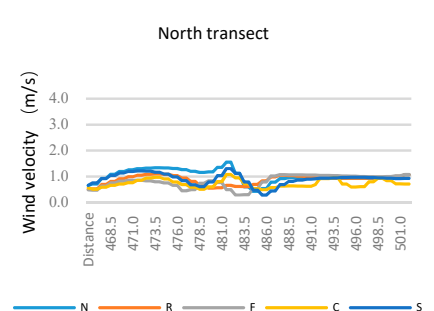

(C)

Figure 13. Transects for the wind velocity from the west to the east: (A) south transect, (B) central transect, $(\mathbf{C})$ north transect.

When designing courtyards, it is recommended that the west and east courtyard parts near the building walls are considered for afternoon activities due to the good local ventilation. Although the wind velocity in the central part is higher than the velocity elsewhere, this area is not recommended due to potential discomfort. Therefore, taking into account the wind velocity conditions, the $\mathrm{C}, \mathrm{R}$ and $S$ patterns are recommended.

\subsection{Impact of the Tree-Planting Pattern on the Wind Direction}

The main wind direction within the courtyard affects the layout and orientation of outdoor furniture. Figure 14 shows the wind flow pattern for five tree-planting pattern scenarios within the

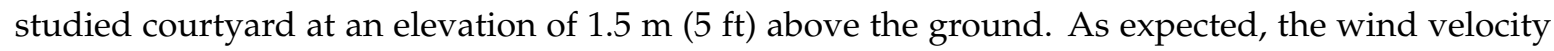

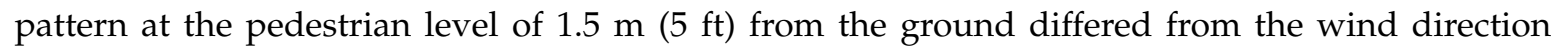


provided by a weather station. The wind flow changed within the courtyard due to the obstructions. Nevertheless, the wind pattern did not change much among the different tree-planting patterns in most of the areas within the courtyard. Buildings were the more important obstructions affecting the wind flow pattern, certainly more important than trees. In the northwest part of the courtyard, the wind flow pattern in the $\mathrm{F}$ and $\mathrm{R}$ planting patterns was different from the wind flow pattern in the other three planting patterns. This result indicates that it is necessary to plant trees in the direction that the wind comes into the courtyard in order to change the wind flow pattern. The wind flow pattern for the $\mathrm{C}, \mathrm{S}$ and $\mathrm{N}$ patterns showed almost the same trend, while the $\mathrm{F}$ and $\mathrm{R}$ patterns were similar, especially in the north part of the courtyard along the north building wall. This means that planting trees in the central part of the courtyard where the wind comes in can be more effective for changing the wind flow pattern than planting trees surrounding the courtyard or putting trees in the north corner. Although the incoming wind direction is from the south, the wind flow pattern within the courtyard in most areas, especially those with high wind velocities, flows from the north and the east. When designing resting facilities such as benches in the courtyard, they should be placed facing north, east or northeast so that the wind flows to the front of the user.

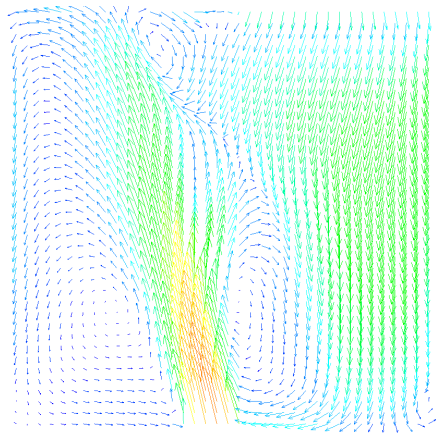

(F)

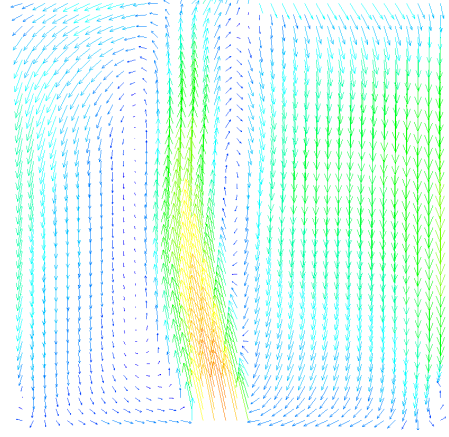

(S)

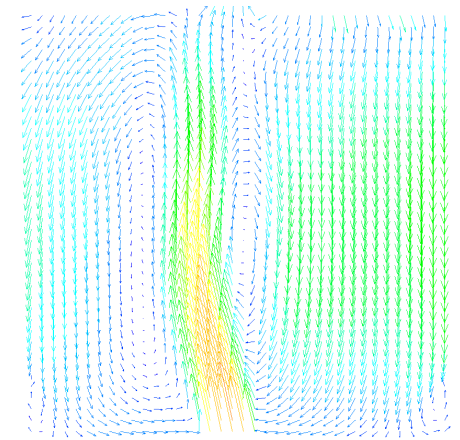

(C)

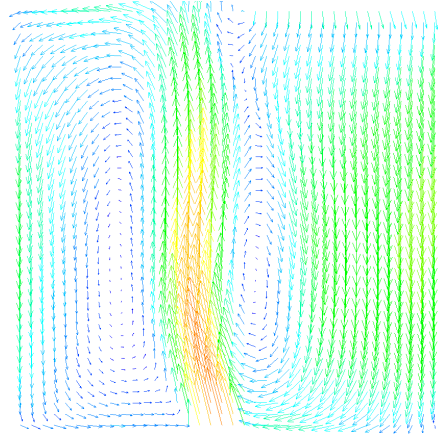

$(\mathrm{N})$

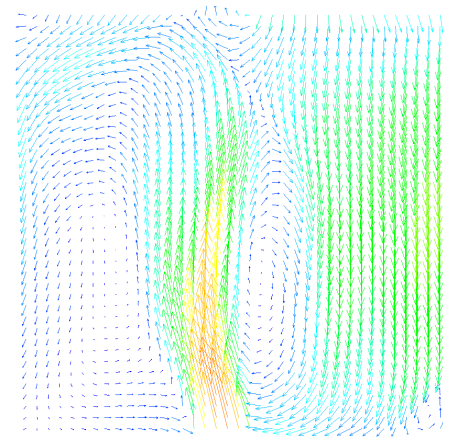

$(\mathrm{R})$

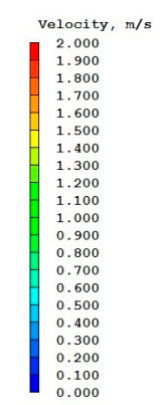

Figure 14. Wind direction for the five tree-planting pattern scenarios within the courtyard $(\mathrm{h}=1.5 \mathrm{~m}$ $(5 \mathrm{ft}))$.

\subsection{Impact of the Tree-Planting Pattern on the Relative Humidity}

On hot humid summer days, the humidity of the air can influence the thermal comfort as well. A high relative humidity will inhibit sweat, thus making people feel uncomfortable on hot summer days. Figure 15 show that all tree-planting patterns had a higher relative humidity at the southwest part of the courtyard, except for the N pattern. The highest relative humidity appeared in the southwest corner of the courtyard for the $\mathrm{R}$ and $\mathrm{S}$ patterns where a vortex formed and the wind velocity was relatively smaller than most of the other parts in the courtyard. For the F pattern, the highest relative humidity appeared in the south part near the entrance of the courtyard where the wind flow comes into the courtyard. A vortex also formed there and the wind velocity was relatively small too. Lower 
relative humidity appeared along the building walls on the north and east sides where the sunshine kept heating the building surface and the temperature was relatively high.

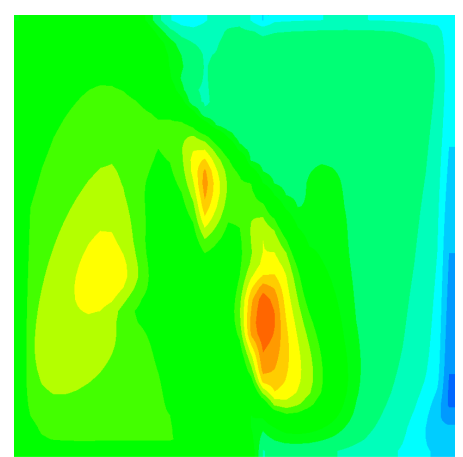

$(\mathrm{F})$

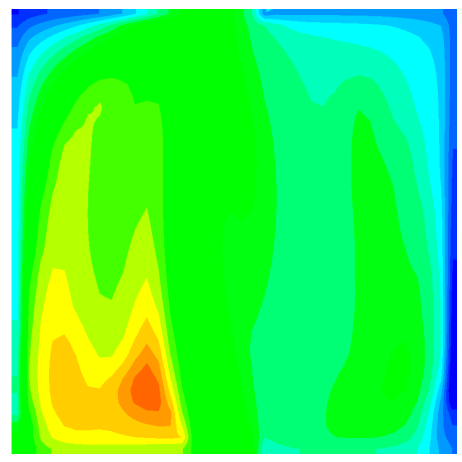

(S)

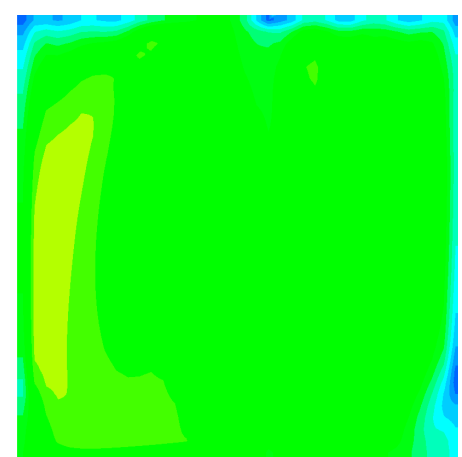

(C)

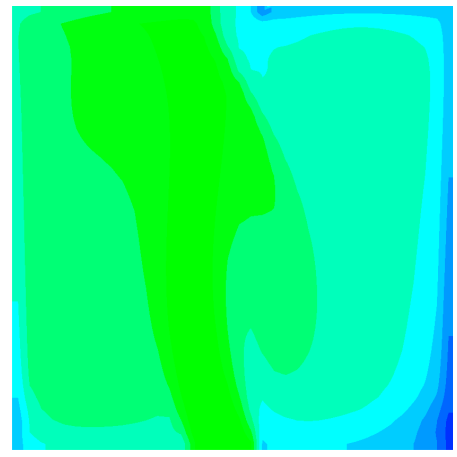

(N)

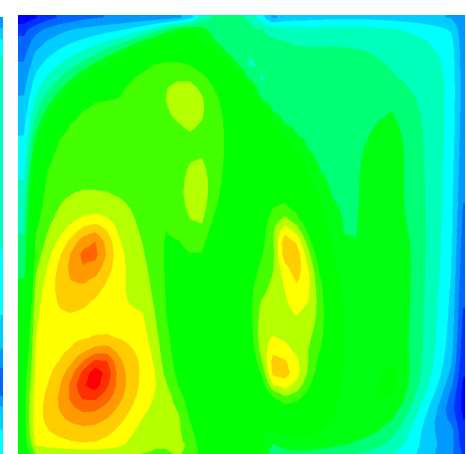

$(\mathrm{R})$

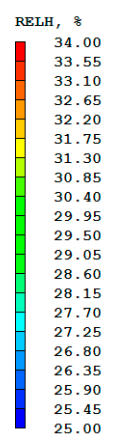

Figure 15. Relative humidity for the five tree-planting pattern scenarios within the courtyard $(\mathrm{h}=1.5 \mathrm{~m}$ $(5 \mathrm{ft}))$.

Figure 16 shows three transects of relative humidity from the west to the east of the courtyard at a height of $1.5 \mathrm{~m}$ high above the ground. The three transects were sampled the same way as those of the air temperature. From Figure 16A, we can see that in the south part along the west building wall, the relative humidity increased by at least $2 \%$ when trees were planted in the courtyard. In the east part, the highest relative humidity was reached when trees were planted in the north corners. Tree planting in rows can make the relative humidity increase more than $4 \%$ and $3.5 \%$, respectively, at the west and east sides of the midlle of the courtyard (Figure 16B). The increase in relative humidity for the $\mathrm{F}$ pattern was higher than that of other patterns in the west part of the courtyard along the north building wall (Figure 16C).

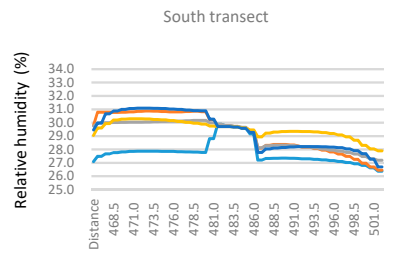

(A)

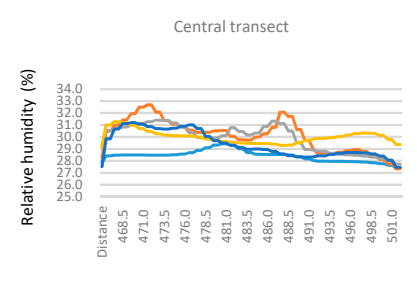

(B)

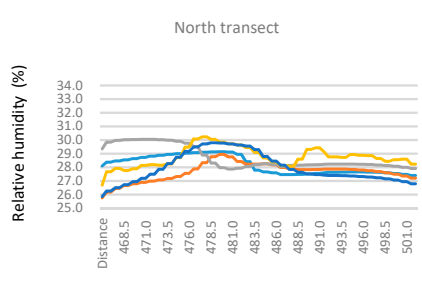

(C)

Figure 16. Transects for the relative humidity from the west to the east: (A) south transect, (B) central transect, $(\mathbf{C})$ north transect. 


\subsection{Discussion}

The worsening urban thermal environment is challenging sustainable urban design. Based on the simulation results, optimized tree-planting patterns for certain design objectives can be determined and relevant design guidelines can be provided. The results of this study are intended to be used by landscape designers to determine tree-planting patterns to optimize the cooling and ventilation effects when designing courtyards.

We developed some design guidelines from this research. Planting trees at the north corner can have the most benefit in terms of decreasing the average air temperature and increasing the average wind speed; avid planting of trees surrounding the courtyard should be done if you want to decrease the average air temperature within the courtyard on hot summer afternoons; cooler areas will change with different tree planting patterns, while hotter areas will not change a lot; the wind direction can be much different from the prevailing one outside the courtyard, so it is necessary to analyze the prevailing wind direction according to the arrangement of the surrounding buildings; if trees are planted surrounding the courtyard or evenly in rows, the design of a staying space in the southwest corner should be avoided to avoid hot humid air.

Zhang [28] stated that the impact of vegetation on both the heat environment and ventilation in hot and cold seasons depends on the tree arrangement, LAI, crown width and tree height. Zhao et al. [42] found that two trees planted without canopy overlap provided the best microclimate and human thermal comfort benefits in the neighborhood due to the importance of shading in a hot, arid desert environment. In this study, we came to the same conclusion: that the arrangement of trees affects the microclimate on hot summer days. This study also further examined the effect of the tree-planting pattern on the microclimate within a courtyard. Even without overlap of the tree canopy, the cooling and ventilation effects on hot summer afternoons are different for different tree planting patterns.

This research was conducted on a hot summer afternoon at 2:00 p.m., which is a specific weather condition. Therefore, the results are limited to a warm summer period and to a specific time of the day which is generally associated with uncomfortable outdoor conditions in warm climates.

The created urban geometry in this study was based on an idealized neighborhood community. This study did not account for smaller landscape elements, such as shrubs, paving and poles. Those elements might affect the local air temperatures and wind velocity, so they should be taken into account. The wind direction did not vary a lot among the different tree-planting patterns in this study. In the future, it is suggested that the influences of the LAI and the drag coefficient of trees, tree-planting density and wind velocity are investigated. If a simulation of $24 \mathrm{~h}$ is done, then suggestions for the usage of the courtyard throughout the day could be given. It is possible to decide which locations in the courtyard should be comfortable for outdoor activities. Also, a tree-planting pattern can be selected based on a whole day's activities in the courtyard and the microclimate at different heights should be investigated for various courtyard activities. Such numerical studies can provide data to determine which tree-planting pattern can provide longer comfort hours during the day. In future work, both the crown size and trunk height should be considered. Additional urban green scenarios with systematically altered coverage of trees, shrubs and grasslands should also be included to provide an understanding of the cooling effect of different configurations of urban greening to be used in design practice.

In this study, we focused on the influence of the tree-planting pattern on the microclimate. However, thermal comfort, which combines the air temperature, wind velocity, relative humidity and other factors, is the more important index that we are concerned with. In the future, we should analyze the impact of the tree-planting pattern on thermal comfort. We should pay attention to different heights according to the activities people undertake in the outdoor environment.

\section{Conclusions}

This paper explored the impacts of tree-planting patterns on the microclimate within a courtyard. The effects of different tree-planting patterns were compared based on CFD numerical simulation 
results. These results show that different tree-planting patterns can lead to differences in air temperature, relative humidity and wind velocity distribution characteristics. Planting trees in a $\mathrm{C}$ pattern in the courtyard can achieve the lowest average air temperature on hot summer afternoons, while the R and S patterns result in lower air temperatures, especially in the southwest part of the courtyard, when compared to the air temperatures in the same areas with the other tree-planting patterns. The maximum temperature drop was $2{ }^{\circ} \mathrm{C}$ in the case of the $\mathrm{S}$ pattern on a hot summer afternoon when compared with the $\mathrm{N}$ pattern. Furthermore, the wind velocity is affected by the density and the locations of the trees planted in the courtyard. The $\mathrm{C}, \mathrm{S}$ and $\mathrm{N}$ patterns resulted in better ventilation in the courtyard, while the $\mathrm{F}$ and $\mathrm{R}$ patterns resulted in lower wind velocities compared to the other tree-planting patterns. The wind flow pattern changed with densely planted trees for the F pattern. Finally, the relative humidity distribution pattern changed with the tree-planting pattern and the relative humidity was able to increase by $4 \%$ at most with different tree-planting patterns at certain points on hot summer afternoons within the courtyard. Overall, further studies involving the design of the landscape within courtyards require further analysis to investigate the mechanisms of the phenomena.

Author Contributions: For research articles with several authors, a short paragraph specifying their individual contributions must be provided. The following statements should be used "conceptualization, J.L. (Junying Li); methodology, J.L. (Junying Li), J.S. and J.L. (Jiying Liu); software, J.L. (Jiying Liu); validation, J.L. (Junying Li) and J.L. (Jiying Liu); formal analysis, J.L. (Junying Li); investigation, J.L. (Junying Li) and J.L. (Jiying Liu); resources, J.S.; data curation, J.L. (Junying Li) and J.L. (Jiying Liu); writing—original draft preparation, J.L. (Junying Li); writing—review and editing, J.L. (Junying Li), J.S., J.L. (Jiying Liu), Y.H. and M.L., S.W.; visualization, L.S. and S.W.; supervision, J.S. and Y.H.

Funding: This study is sponsored by the National Natural Science Foundation of China (NSFC, No.31670703, 51608310, 41671185, 41671184), China National R \& D Program (No. 2017YFC0505704) and the China Scholarship Council program.

Acknowledgments: The authors would like to express the gratitude to the University of Maryland for the access to computational resources and experimental facilities. The authors would like to thank Jinfeng Lu, Mengyao Ma and Wenqi $\mathrm{Wu}$ for their support with the data analyses of the simulation results. The authors are also grateful to Mr. Peter Spalding, the manager at CHAM Limited, for the discounted software license.

Conflicts of Interest: The authors declare no conflict of interest.

\section{List of Abbreviations and Symbols Used}

$\beta p \quad$ the fraction of mean-flow kinetic energy converted to wake-generated $k$ by canopy drag.

$\beta d \quad$ the fraction of $k$ dissipated by short-circuiting the Kolmogorov

energy cascade.

$K$ the von Karman constant.

$u^{*} \quad$ the friction velocity

$z_{0} \quad$ the roughness length.

Fs the safe factor.

$\varepsilon \quad$ the error between the current and refined mesh

$r \quad$ the grid improvement factor.

$P \quad$ the order of convergence.

F focused tree-planting.

C cornered tree-planting

$\mathrm{R} \quad$ multi-row tree-planting

$\mathrm{S} \quad$ surround tree-planting

$\mathrm{N}$ no tree-planting

UHI Urban Heat Island

RNG Re-Normalization Group

CFD Computational Fluid Dynamics.

LAI Leaf Area Index 


\section{References}

1. Qin, Y. A review on the development of cool pavements to mitigate urban heat island effect. Renew. Sustain. Energy Rev. 2015, 52, 445-459. [CrossRef]

2. Taleghani, M. Outdoor thermal comfort by different heat mitigation strategies-A review. Renew. Sustain. Energy Rev. 2018, 81(Part 2), 2011-2018. [CrossRef]

3. Saito, I.; Ishihara, O.; Katayama, T. Study of the effect of green areas on the thermal environment in an urban area. Energy Build. 1990, 15, 493-498. [CrossRef]

4. Srivanit, M.; Hokao, K. Evaluating the cooling effects of greening for improving the outdoor thermal environment at an institutional campus in the summer. Build. Environ. 2013, 66, 158-172. [CrossRef]

5. Santamouris, M.; Ding, L.; Fiorito, F.; Oldfield, P.; Osmond, P.; Paolini, R.; Prasad, D.; Synnefa, A. Passive and active cooling for the outdoor built environment-Analysis and assessment of the cooling potential of mitigation technologies using performance data from 220 large scale projects. Solar Energy 2017, 154, 14-33. [CrossRef]

6. Tsoka, S. Investigating the Relationship Between Urban Spaces Morphology and Local Microclimate: A Study for Thessaloniki. Procedia Environ. Sci. 2017, 38, 674-681. [CrossRef]

7. Taleghani, M.; Sailor, D.J.; Tenpierik, M.; van den Dobbelsteen, A. Thermal assessment of heat mitigation strategies: The case of Portland State University, Oregon, USA. Build. Environ. 2014, 73, 138-150. [CrossRef]

8. Gago, E.J.; Roldan, J.; Pacheco-Torres, R.; Ordóñez, J. The city and urban heat islands: A review of strategies to mitigate adverse effects. Renew. Sustain. Energy Rev. 2013, 25, 749-758. [CrossRef]

9. O'Malley, C.; Piroozfar, P.; Farr, E.R.P.; Pomponi, F. Urban Heat Island (UHI) mitigating strategies: A case-based comparative analysis. Sustain. Cities Soc. 2015, 19, 222-235. [CrossRef]

10. Lambers, H.; Chapin, S., III. Plant Physiological Ecology; Springer: New York, NY, USA, 1998.

11. Kantzioura, A.; Kosmopoulos, P.; Dimoudi, A.; Zoras, S. Experimental investigation of microclimatic conditions in relation to the built environment in a central urban area in Thessaloniki (Northern Greece): A case study. Sustain. Cities Soc. 2015, 19, 331-340. [CrossRef]

12. Zamani, Z.; Heidari, S.; Hanachi, P. Reviewing the thermal and microclimatic function of courtyards. Renew. Sustain. Energy Rev. 2018, 93, 580-595. [CrossRef]

13. Nasrollahi, N.; Hatami, M.; Khastar, S.R.; Taleghani, M. Numerical evaluation of thermal comfort in traditional courtyards to develop new microclimate design in a hot and dry climate. Sustain. Cities Soc. 2017, 35, 449-467. [CrossRef]

14. Kubota, T.; Zakaria, M.A.; Abe, S.; Toe, D.H.C. Thermal functions of internal courtyards in traditional Chinese shophouses in the hot-humid climate of Malaysia. Build. Environ. 2017, 112, 115-131. [CrossRef]

15. Taleghani, M. Dwelling on Courtyards-Exploring the Energy Efficiency and Comfort Potential of Courtyards for Dwellings in the Netherlands; Mohammad Taleghani: Delft, The Netherlands, 2014.

16. Jamei, E.; Rajagopalan, P.; Seyedmahmoudian, M.; Jamei, Y. Review on the impact of urban geometry and pedestrian level greening on outdoor thermal comfort. Renew. Sustain. Energy Rev. 2016, 54, 1002-1017. [CrossRef]

17. Paas, B.; Schneider, C. A comparison of model performance between ENVI-met and Austal2000 for particulate matter. Atmos. Environ. 2016, 145, 392-404. [CrossRef]

18. Gromke, C.; Blocken, B.; Janssen, W.; Merema, B.; van Hooff, T.; Timmermans, H. CFD analysis of transpirational cooling by vegetation: Case study for specific meteorological conditions during a heat wave in Arnhem, Netherlands. Build. Environ. 2015, 83, 11-26. [CrossRef]

19. Chatzidimitriou, A.; Yannas, S. Microclimate development in open urban spaces: The influence of form and materials. Energy Build. 2015, 108, 156-174. [CrossRef]

20. Zheng, S.; Zhao, L.; Li, Q. Numerical simulation of the impact of different vegetation species on the outdoor thermal environment. Urban For. Urban Green. 2016, 18, 138-150. [CrossRef]

21. Lin, B.; Li, X.; Zhu, Y.; Qin, Y. Numerical simulation studies of the different vegetation patterns' effects on outdoor pedestrian thermal comfort. J. Wind Eng. Ind. Aerodyn. 2008, 96, 1707-1718. [CrossRef]

22. Morakinyo, T.E.; Kong, L.; Lau, K.K.-L.; Yuan, C.; Ng, E. A study on the impact of shadow-cast and tree species on in-canyon and neighborhood's thermal comfort. Build. Environ. 2017, 115, 1-17. [CrossRef]

23. Tan, Z.; Lau, K.K.-L.; Ng, E. Planning strategies for roadside tree planting and outdoor comfort enhancement in subtropical high-density urban areas. Build. Environ. 2017, 120, 93-109. [CrossRef] 
24. Tan, Z.; Lau, K.K.-L.; Ng, E. Urban tree design approaches for mitigating daytime urban heat island effects in a high-density urban environment. Energy Build. 2016, 114, 265-274. [CrossRef]

25. Ng, W.Y.; Chau, C.K. Evaluating the role of vegetation on the ventilation performance in isolated deep street canyons. Int. J.Environ. Pollut. 2012, 50, 98-110. [CrossRef]

26. Gromke, C.; Buccolieri, R.; Di Sabatino, S.; Ruck, B. Dispersion study in a street canyon with tree planting by means of wind tunnel and numerical investigations - Evaluation of CFD data with experimental data. Atmos. Environ. 2008, 42, 8640-8650. [CrossRef]

27. Hsieh, C.-M.; Jan, F.-C.; Zhang, L. A simplified assessment of how tree allocation, wind environment, and shading affect human comfort. Urban For. Urban Green. 2016, 18, 126-137. [CrossRef]

28. Zhang, L.; Zhan, Q.; Lan, Y. Effects of the tree distribution and species on outdoor environment conditions in a hot summer and cold winter zone: A case study in Wuhan residential quarters. Build. Environ. 2018, 130, 27-39. [CrossRef]

29. Cham, L. PHOENICS Software, Version 2015 (64bit Intel); Cham Ltd.: London, UK; Wimbledon: London, UK, 2016.

30. Wu, J.; Ludwig, J. Flair User's Guide, Documentation fo Phoenics TR 313. Version: 2010; Cham Ltd.: London, UK, 2010.

31. Finnigan, J. Turbulence in plant canopies. Annu. Rev. Fluid Mech. 2000, 32, 519-571. [CrossRef]

32. Green, S. Modeling Turbulent Air Flow in a Stand of Widely Spaced Trees. PHOENICS J. Comput. Fluid Dyn. Appl. 1992, 5, 294-312.

33. Blocken, B.; Carmeliet, J. High-resolution wind-driven rain measurements on a low-rise building-Experimental data for model development and model validation. J. Wind Eng. Ind. Aerodyn. 2005, 93, 905-928. [CrossRef]

34. Richards, P.; Hoxey, R. Appropriate boundary conditions for computational wind engineering models using the k- $\varepsilon$ turbulence model. In Computational Wind Engineering 1; Elsevier: Amsterdam, The Netherlands, 1993; pp. 145-153.

35. Blocken, B.; Stathopoulos, T.; Carmeliet, J. CFD simulation of the atmospheric boundary layer: Wall function problems. Atmos. Environ. 2007, 41, 238-252. [CrossRef]

36. Liu, N.; Qin, Y. Building Thermal Environment; Tsinghua University Press: Beijing, China, 2005.

37. Liu, J.; Heidarinejad, M.; Gracik, S.; Srebric, J. The impact of exterior surface convective heat transfer coefficients on the building energy consumption in urban neighborhoods with different plan area densities. Energy Build. 2015, 86, 449-463. [CrossRef]

38. Liu, J.; Srebric, J.; Yu, N. Numerical simulation of convective heat transfer coefficients at the external surfaces of building arrays immersed in a turbulent boundary layer. Int. J. Heat Mass Transf. 2013, 61, 209-225. [CrossRef]

39. Mochida, A.; Tominaga, Y.; Yoshie, R. AIJ guideline for practical applications of CFD to wind environment around buildings. In Proceedings of the 4th International Symposium on Computational Wind Engineering (CWE2006), Yokohama, Japan, 16-19 July 2006.

40. Tominaga, Y.; Mochida, A.; Yoshie, R.; Kataoka, H.; Nozu, T.; Yoshikawa, M.; Shirasawa, T. AIJ guidelines for practical applications of CFD to pedestrian wind environment around buildings. J. Wind Eng. Ind. Aerodyn. 2008, 96, 1749-1761. [CrossRef]

41. Houborg, R.; McCabe, M.F. A hybrid training approach for leaf area index estimation via Cubist and random forests machine-learning. ISPRS J. Photogramm. Remote Sens. 2018, 135, 173-188. [CrossRef]

42. Zhao, Q.; Sailor, D.J.; Wentz, E.A. Impact of tree locations and arrangements on outdoor microclimates and human thermal comfort in an urban residential environment. Urban For. Urban Green. 2018, 32, 81-91. [CrossRef]

(C) 2019 by the authors. Licensee MDPI, Basel, Switzerland. This article is an open access article distributed under the terms and conditions of the Creative Commons Attribution (CC BY) license (http:// creativecommons.org/licenses/by/4.0/). 